\section{Galería Benot}

www.galeriabenot.com

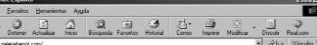

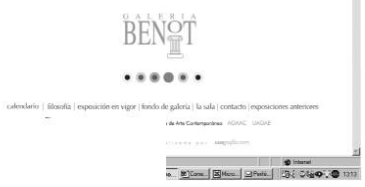

Es de agradecer en un Ecampo tan enrevesado a veces como es el de las páginas WEB una solución tan clara y limpia como la que se nos plantea en la página de Galería Benot. Más aún si estamos hablando de arte contemporáneo, un campo que abarca las más diversas expresiones pero que desde esta ventana virtual se nos muestra relajado, agradable y fácil en todas sus facetas.

Esta galería virtual refleja perfectamente el espíritu de su fundador Rafael Benot y su vocación de canalizador de tendencias artísticas para darlas a conocer al público de Cádiz. Desde su fundación en 1992 han pasado por la galería, y desde hace dos años por su reflejo virtual en Internet, multitud de creadores de las más diversas tendencias que en su conjunto han sido y lo siguen siendo un perfecto exponente de la realidad del arte contemporáneo en el sur de España.

La web de la galería está estructurada en 7 campos perfectamente interelacionados. A través de su navegación se nos muestra de una manera clara no solo la exposición que está teniendo lugar en la galería sino un calendario de lo que ha habido y lo que habrá, sin perder en ningún momento esa elegancia de diseño y navegación de la que hablábamos al principio. Incluso podemos acceder a un magnífico y muy surtido fondo de galería donde podemos deleitarnos con piezas de exposiciones anteriores que de una manera realmente dinámica, no olvidemos que estamos hablando siempre de imágenes, nos muestran piezas que aún están a la venta de exposiciones ya realizadas.

Es quizás este detalle, la profusión de imágenes en la página, lo más característico de ella. Cosa lógica si se para uno a pensarlo ya que hablamos de arte contemporáneo, fundamentalmente visual. Pero no por lógico es muy abundante encontrar páginas que resuelvan de una manera tan ágil esa manera de mostrar ese volumen visual sin que resulte pesado.

Por buscar algún defecto pueden echarse en falta algunos links a otras páginas del sector lo que acabaría de convertir a esta página en una auténtica puerta de entrada al mundo del arte contemporáneo en Andalucía.
Gestión Cultural

El Portal Iberoamericano de Gestión Cultural

www.gestioncultural.org

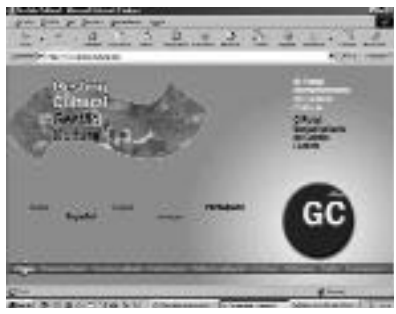

Dromovido por los organizadores del Master de Gestión Cultural de la Universidad de Barcelona -en especial por el Profesor Lluís Bonet-, el portal iberoamericano de gestión cultural es todo un descubrimiento y una necesidad para nuestro mundo profesional.

Con una presentación gráfica limpia e impecable, el portal nació con dos premisas básicas: su carácter gratuito -siempre hay que decir que por ahora- y su vocación de servicio a los profesionales de la gestión cultural en Iberoamérica (de ahí sus dos versiones en español y portugués).

Nos hallamos, pues, ante una herramienta obligada de trabajo ya que el portal tiene una estructura y 